\title{
A Review of the Cyanidation Treatment of Copper-Gold Ores and Concentrates
}

\author{
Diego Medina * and Corby G. Anderson \\ Department of Mining Engineering, Kroll Institute for Extractive Metallurgy Colorado School of Mines \\ 1500 Illinois St., Hill Hall 337, Golden, CO 80401, USA; cganders@mines.edu \\ * Correspondence: diegomedina@mymail.mines.edu; Tel.: +1-720-630-5159
}

Received: 21 May 2020; Accepted: 23 June 2020; Published: 5 July 2020

\begin{abstract}
Globally, copper, silver, and gold orebody grades have been dropping, and the mineralogy surrounding them has become more diversified and complex. The cyanidation process for gold production has remained dominant for over 130 years because of its selectivity and feasibility in the mining industry. For this reason, the industry has been adjusting its methods for the extraction of gold, by utilizing more efficient processes and technologies. Often, gold may be found in conjunction with copper and silver in ores and concentrates. Hence, the application of cyanide to these types of ores can present some difficulty, as the diversity of minerals found within these ores can cause the application of cyanidation to become more complicated. This paper outlines the practices, processes, and reagents proposed for the effective treatment of these ores. The primary purpose of this review paper is to present the hydrometallurgical processes that currently exist in the mining industry for the treatment of silver, copper, and gold ores, as well as concentrate treatments. In addition, this paper aims to present the most important challenges that the industry currently faces, so that future processes that are both more efficient and feasible may be established.
\end{abstract}

Keywords: gold cyanide leaching; sulfide minerals; SART process; cyanidation; activated carbon; metal-cyanide complex; copper ore; carbon in pulp (CIP), agitated tank; cyanide complexes

\section{Introduction}

The history of modern hydrometallurgy started with the discovery of how to obtain gold and silver from ores, on 19 October 1887, by John Steward MacArthur, who was recognized for having established the application of the cyanidation process. Gold production around the world readily doubled as a consequence of cyanidation's initial application within the mining industry. Following the first application of cyanidation in the recovery of gold, the hydrometallurgical industry has developed and grown according to the needs of the process and the mineral complexity of the ore deposits.

Hydrometallurgical processes can be defined as the leaching of a desired metal into a solution, followed by the concentration and purification of the pregnant solution, and finally, the recovery of the metal or its compounds. The processing of gold and silver ore by leaching is one of the most prominent examples of early hydrometallurgy-based processes.

Most of the gold extraction from ore is accomplished by the implementation of an alkaline cyanide leaching process. The chemical recovery of gold can be defined by two different operations: the oxidative dissolution of gold and the reductive precipitation of metallic gold from the solution. Cyanide is one of the most attractive lixiviants in the current industrial gold leaching process. During gold cyanidation, silver and copper are commonly present within the solution, which causes their metal ions to react with the cyanide $\left(\mathrm{CN}^{-}\right)$, thus forming complexes [1].

Cyanide is considered to be a hazardous compound because of its toxicity; there is currently environmental pressure by different groups around the world to ban the industrial use of cyanide. 
Research on replacing cyanide as a lixiviant has been ongoing over the years, and has found that there are other potentially workable compounds, such as thiosulfate, thiourea, halides, various sulfide systems, ammonia, bacteria, natural acids, thiocyanate, nitriles, and combinations of cyanide with other compounds [1]. Many of these alternative gold processes are still in the early development stages. A key factor for the commercial success of these alternative lixiviants relates to the overall stability of the lixiviant and the gold complex in solution.

Currently, the mining industry faces the problem of separating these complex valuable minerals from the ore in which they reside. This paper outlines various options that hydrometallurgical processes offer for the treatment of these complex minerals, containing precious metals such as $\mathrm{Cu}, \mathrm{Ag}$, and $\mathrm{Au}$.

\section{Copper Mineral Complexity}

The fact that the majority of copper ore deposits are complex has resulted in the better development of technologies able to extract precious metals more efficiently. Table 1 shows some of the sulfide minerals that can be found during the treatment of ores containing $\mathrm{Cu}, \mathrm{Ag}$, and $\mathrm{Au}$ ores.

Table 1. Main sulfide minerals for copper ores [2].

\begin{tabular}{ccc}
\hline Sulfide Mineral & Element & Formula \\
\hline Chalcopyrite & & $\mathrm{CuFeS}_{2}$ \\
Chalcocite & Copper & $\mathrm{Cu}_{2} \mathrm{~S}$ \\
Covellite & $\mathrm{CuS}$ \\
Bornite & & $\mathrm{Cu}_{5} \mathrm{FeS}_{4}$ \\
\hline Pyrite & Iron & $\mathrm{FeS}_{2}$ \\
Pyrholite & & $\mathrm{FeS}$ \\
Argentite & Silver & $\mathrm{Ag}_{2} \mathrm{~S}$ \\
\hline
\end{tabular}

Copper sulfide deposits around the world are commonly associated with copper oxide minerals. Generally, copper oxide minerals do not respond to standard sulfide copper collectors and require the application of different flotation techniques [3]. The treatment of copper sulfide minerals containing a high percentage of oxide copper causes problems in the concentration process, decreasing the copper content. In order to increase the efficiency of the concentration process, it is necessary to treat the copper oxide component by leaching the grinded ore prior to the flotation, or by leaching the flotation tailings coming out from the concentrator [4,5].

\section{Cyanidation of Complex Gold Ores and Concentrates}

The cyanidation process has become one of the most used methods for the recovery of gold from ores. The use of cyanide leaching for gold recovery is based on gold's properties, whereby gold does not become oxidized at ordinary temperatures. Additionally, gold is not soluble in sulphuric, hydrochloric, or nitric acids, but can be dissolved in aqua regia (a mixture of nitric and hydrochloric acid). On the other hand, the most crucial fact about gold, in this case, is that it is soluble in dilute cyanide solutions. For this reason, cyanide is used as a lixiviant during the leaching process in order to perform the gold extraction through the use of this hydrometallurgical process [6]

Figure 1 shows that the hydrometallurgical process starts with the leaching agitators, where the slurry comes into contact with cyanide, oxygen, water, and lime, thereby enacting the leaching process. During the leaching process, other cyanide complexes, such as copper and silver sulfide minerals, are formed. The following cyanide complexes are formed during this stage of the cyanidation:

- Gold cyanide reaction:

$$
4 \mathrm{Au}+8 \mathrm{NaCN}+2 \mathrm{H}_{2} \mathrm{O}+\mathrm{O}_{2} \rightarrow 4 \mathrm{NaAu}(\mathrm{CN})_{2}+4 \mathrm{NaOH}
$$

- Silver cyanide reaction: 


$$
4 \mathrm{Ag}+8 \mathrm{NaCN}+2 \mathrm{H}_{2} \mathrm{O}+\mathrm{O}_{2} \rightarrow 4 \mathrm{NaAg}(\mathrm{CN})_{2}+4 \mathrm{NaOH}
$$

In this case, the copper sulfide minerals can form complexes with cyanide, such as $\mathrm{Cu}(\mathrm{CN})_{2}$, as the following reaction shows:

- Copper cyanide reaction:

$$
4 \mathrm{Cu}+8 \mathrm{NaCN}+2 \mathrm{H}_{2} \mathrm{O}+\mathrm{O}_{2} \rightarrow 4 \mathrm{NaCu}(\mathrm{CN})_{2}+4 \mathrm{NaOH}
$$

The formation of copper and silver cyanide complexes affects the gold recovery in both the cyanide leaching process as well as the purification and refining stages [7]. These effects mainly interfere with the gold cyanide reaction and the carbon adsorption. Most of the copper minerals react rapidly with cyanide, forming multiple cyanide complexes. Table 2 shows the solubility of copper minerals in a cyanide solution. As can be shown, chalcopyrite is the copper mineral with the lowest percentage of copper dissolved and extracted, when compared to the other minerals [8].

Table 2. Solubility of copper minerals in $0.1 \% \mathrm{NaCN}$ solutions. Reproduced and adapted from [8],

\begin{tabular}{|c|c|c|c|c|c|}
\hline \multirow[t]{2}{*}{ Mineral } & \multirow[t]{2}{*}{ Formula } & \multicolumn{2}{|c|}{ Percent Total Copper Dissolved ${ }^{a}$} & \multirow[t]{2}{*}{$\mathrm{g} \mathrm{NaCN} / \mathrm{g} \mathrm{Cu}^{\mathrm{b}}$} & \multirow[t]{2}{*}{ Extraction $(\% \mathrm{Cu})^{b}$} \\
\hline & & $23 \mathrm{C}$ & $45 \mathrm{C}$ & & \\
\hline Azurite & $2 \mathrm{Cu}(\mathrm{CO})_{3} \cdot \mathrm{Cu}(\mathrm{OH})_{2}$ & 94.5 & 100 & 3.62 & 91.8 \\
\hline Malachite & $2 \mathrm{CuCO}_{3}(\mathrm{OH})_{2}$ & 90.2 & 100 & 4.48 & 99.7 \\
\hline Chalcocite & $\mathrm{Cu}_{2} \mathrm{~S}$ & 90.2 & 100 & 2.76 & 92.6 \\
\hline Covellite & CuS & - & - & 5.15 & 95.6 \\
\hline Native Copper & $\mathrm{Cu}$ & 90 & 100 & - & - \\
\hline Cuprite & $\mathrm{Cu}_{2} \mathrm{O}$ & 85.5 & 100 & 4.94 & 96.6 \\
\hline Bornite & $\mathrm{FeS} \cdot 2 \mathrm{Cu}_{2} \cdot \mathrm{CuS}$ & 70 & 100 & 5.13 & 96 \\
\hline Enargite & $\mathrm{Cu}_{3} \mathrm{AsS}_{4}$ & 65.8 & 75.1 & - & - \\
\hline Tetrahedrite & $(\mathrm{Cu}, \mathrm{Fe}, \mathrm{Ag}, \mathrm{Zn})_{12} \mathrm{Sb}_{4} \mathrm{~S}_{13}$ & 21.9 & 43.7 & - & - \\
\hline Chrysocolla & $\mathrm{CuSiO}_{3} \cdot n \mathrm{H}_{2} \mathrm{O}$ & 11.8 & 15.7 & - & - \\
\hline Chalcopyrite & $\mathrm{CuFeS}_{2}$ & 5.6 & 8.2 & 2.79 & 5.8 \\
\hline
\end{tabular}
with permission from Elsevier B.V., 2005.

${ }^{a}$ Data after Hedley and Tabachnick (1958). ${ }^{\text {b }}$ Data after Lower and Booth (1965). Cyanide consumption is expressed as $\mathrm{g}$. NaCN/g of contained copper, data being generateed by leaching at room temperature for $6 \mathrm{~h}$.

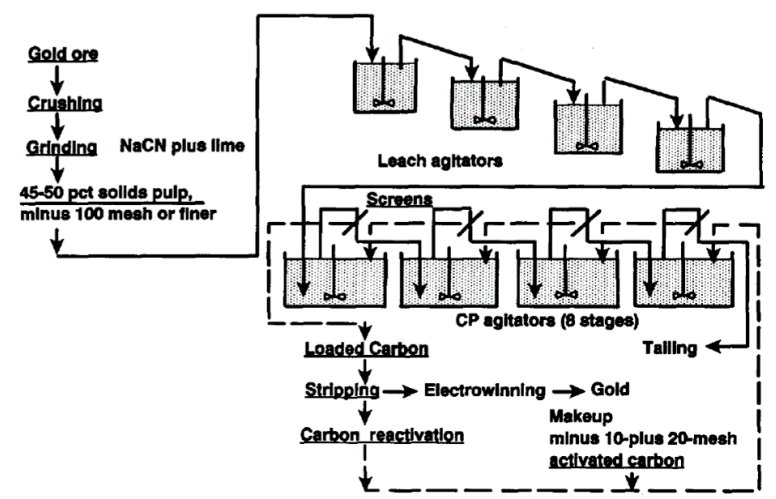

Figure 1. Diagram of gold cyanide leaching using activated carbon recovery. Reproduced and adapted from [9], with permission from PERGAMON, 1987.

There are high carbon-management and bullion-refining costs related to the interference of these cyanide complexes. The $\mathrm{pH}$ in the cyanide solution during the leaching plays an important role. The range of the cyano complexes depends on conditions such as the cyanide concentration and $\mathrm{pH}$, as shown in Figure 2, where at an operational $\mathrm{pH}$ range of 10-11 there is a greater concentration of the complex $\mathrm{Cu}(\mathrm{CN})_{4}{ }^{3-}[8]$. 


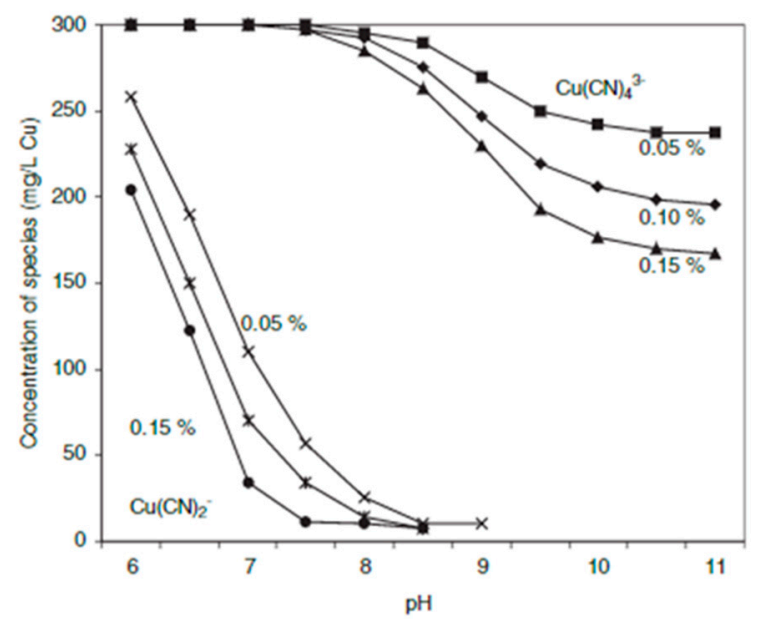

Figure 2. Comparison of cyanide species vs. pH. Reproduced and adapted from [8], with permission from Elservier B.V., 2005.

\section{Cyanide Consumption}

The formation of copper and silver cyanide complexes during the first stage of the leaching process affects the cyanide consumption for gold recovery. Consequently, the operational costs for cyanidation have increased significantly. As an approximation for cyanide, for every $\$ 3600 / t$ delivered to a mine site, it takes only $0.28 \mathrm{~kg} / \mathrm{t}$-ore of consumption to equate to $\$ 1 / \mathrm{t}$-ore or $1 \%$ of gold recovery [9]. Cyanide consumption remains one of the main economic considerations.

The behavior of a specific ore or concentrate in testing can be determined by performing rolled-bottle testing, or, alternatively, by testing in stirred vessels to measure the quantity of cyanide consumption per unit weight of ore. This value can be scaled up for engineering design purposes. The following factors affect cyanide consumption during the leaching process: The functions of ore mineralogy; Cyanide concentration; and Reaction kinetics [10].

A key factor to consider is the effects of the residence time and the pulp density during the cyanide leaching. The residence time determines and controls the reaction rate of the cyanide and oxygen at the surface of the free particles. The optimum time of the reaction for forming gold-cyanide complexes is reached within the first hours of the reaction [7].

The second important aspect to consider is the pulp density during the cyanide reaction. $\mathrm{NaCN}$ consumption decreases as the percentage of solids increases with different cyanide concentrations, meaning that if there is not an appropriate level of gold extraction from within the slurry, the cyanide consumption will be higher, as shown in Figure 3.

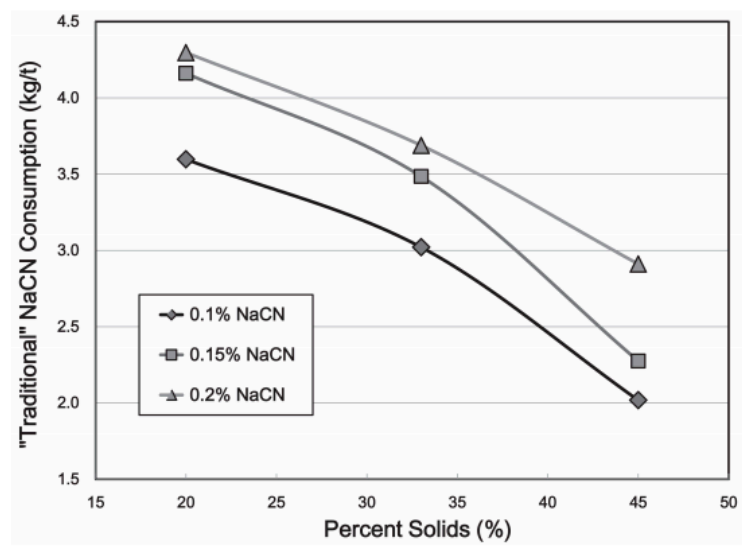

Figure 3. Consumption (kg/t) vs. percent solids (\%) of NaCN. Reproduced and adapted from [7], with permission from Springer, 2015. 


\section{Gold Cyanidation in Copper Flotation Tailings}

The production of copper concentrates from copper-gold sulfide minerals by froth flotation generally results in tailings with copper, silver, and gold values. The cyanidation of copper flotation tailings containing sulfides for gold recovery is an example of the formation of cyanide complexes with copper and silver during the leaching process [11,12]. Figure 4 shows the MLA Automated Minerology image of an ore sample from a copper mine in Mexico, containing chalcopyrite and bornite as copper sulfide minerals.

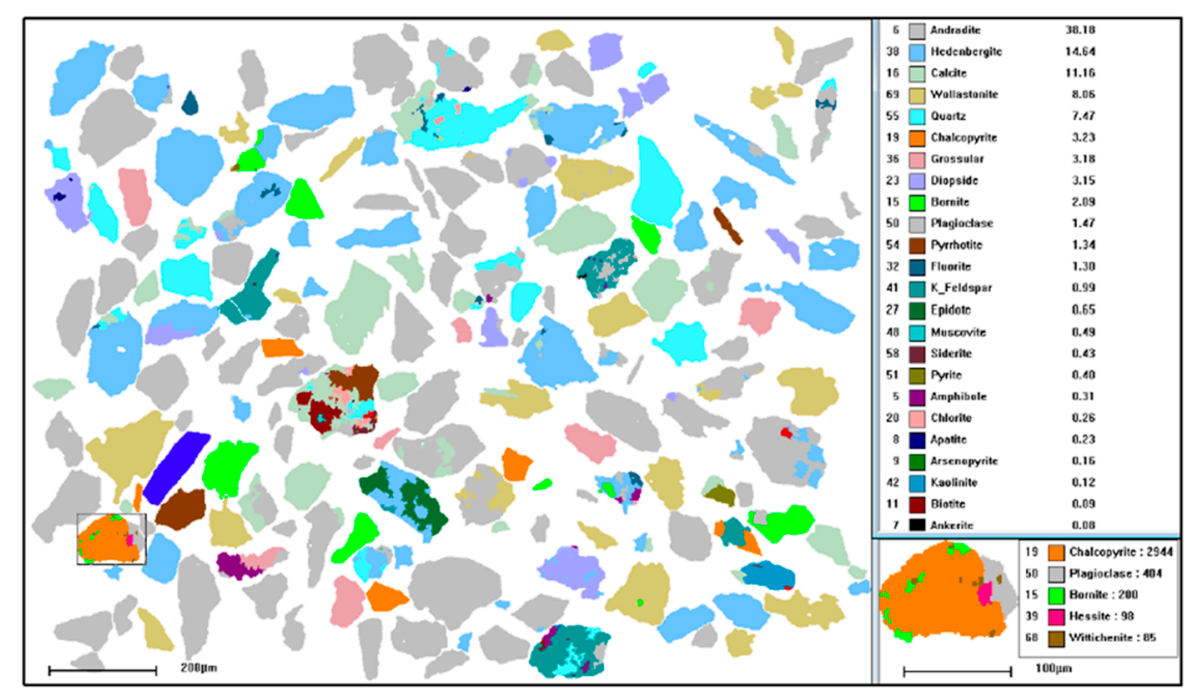

Figure 4. Image containing copper sulfide minerals. Reproduced and adapted from [13], with permission from the authors, 2020.

Studies were performed to analyze the gold recovery by cyanide leaching in the flotation tailings from this ore. There were considerable quantities of copper and silver in the tested tailings that could form cyanide complexes during the cyanide leaching. The beneficiation plant at this particular mine in Mexico produces a copper concentrate, however their flotation circuit only recovers around $75 \%$ of the gold; the rest is lost in the tailings $[14,15]$.

Table 3 shows the results of the cyanide leaching performed on the flotation tailings of this Mexican beneficiation plant using a $\mathrm{NaCN}$ concentration of $0.5 \mathrm{mg} / \mathrm{L}$. The copper and silver recovery percentage values were $33 \%$ and $35 \%$, respectively, which means that most of the copper and silver values were lost in the leaching tailings, as shown in Table 4 . The oxygen concentration was measured during the test to control the oxygen supply as it is needed for the gold leaching. [16]. These copper and silver values may represent a problem relating to the recirculation of the cyanide during leaching; for this reason, the implementation of a cyanide-cleaning detox process is advised [17].

The copper and silver that form cyanide complexes during the gold cyanidation can cause issues during the activated carbon adsorption, for example, by competing with the gold to be adsorbed, therefore requiring a higher free cyanide concentration [18]. In addition, the mineralogy consists of copper sulfide minerals, as previously mentioned. It is expected that the cyanide-barren solution retains a high sulfide content, which can be removed using the SART process discussed in this paper [19].

As mentioned, the process of treating large amounts of cyanide-contaminated effluents remains a challenge in the cyanidation process. The effluents contain free cyanide and metal-cyanide complexes that, in this specific case, would present as copper and silver complexes [20,21]. 
Table 3. Cyanide leaching results of copper-gold minerals. Reproduced from [13], with the permission from the authors.

\begin{tabular}{|c|c|c|c|c|c|c|c|c|c|c|}
\hline \multicolumn{3}{|c|}{ Conditions } & \multicolumn{4}{|c|}{ Assay (mg/kg) } & & \multicolumn{3}{|c|}{ Distribution \% } \\
\hline $\mathrm{NaCN}$ concentration $(\mathrm{mg} / \mathrm{L})$ & Time (h) & Dissolved Oxygen (mg/L) & $\mathrm{pH}$ & $\mathrm{Au}$ & $\mathrm{Ag}$ & $\mathrm{Cu}$ & & $\mathrm{Au}$ & $\mathrm{Ag}$ & $\mathrm{Cu}$ \\
\hline \multirow{7}{*}{0.5} & 0.00 & 5.55 & 11.61 & 0.00 & 0.00 & 0.00 & & 0.00 & 0.00 & 0.00 \\
\hline & 2.00 & 4.87 & 11.60 & 0.11 & 0.45 & 85.31 & & 12.00 & 7.20 & 10.73 \\
\hline & 6.00 & 4.75 & 11.75 & 0.18 & 0.76 & 135.00 & & 18.53 & 12.16 & 16.98 \\
\hline & 17.00 & 4.34 & 11.62 & 0.21 & 1.24 & 186.80 & & 22.11 & 19.84 & 23.49 \\
\hline & 24.00 & 4.29 & 11.70 & 0.22 & 1.70 & 190.00 & & 23.16 & 27.20 & 23.90 \\
\hline & 32.00 & 3.80 & 11.71 & 0.23 & 2.10 & 198.00 & & 24.21 & 33.60 & 24.90 \\
\hline & \multicolumn{2}{|c|}{ Recovery \% } & & 81.79 & 33.33 & 35.59 & Head (Calc) & 100.00 & 100.00 & 100.00 \\
\hline
\end{tabular}

Table 4. Leaching tailings elemental analysis. Reproduced from [13], with the permission from the authors, 2020.

\begin{tabular}{cccc}
\hline Sample & $\mathbf{A u}(\mathbf{m g} / \mathbf{k g})$ & $\mathbf{A g}(\mathbf{m g} / \mathbf{k g})$ & $\mathbf{C u}(\%)$ \\
\hline A & 0.10 & 2.00 & 0.04 \\
B & 0.08 & 6.04 & 0.072 \\
\hline
\end{tabular}

\section{Alternatives Lixiviants to Cyanide}

As mentioned in Section 1 there are alternative gold processes that utilize alternative lixiviants from cyanide. Table 5 shows the stability constants and standard reduction potentials for gold complexes. Clearly, the cyanide complex is more stable and inherently more selective than any other alternative reagent. For example, thiosulfate, thiourea, and bisulfide are several orders of magnitude less stable.

Table 5. Constants and standard reduction potentials for Au complexes at $25^{\circ} \mathrm{C}$. Reproduced and adapted from [4], with permission from Elsevier B.V., 2016.

\begin{tabular}{|c|c|c|c|c|}
\hline Ligand & Au(I)or Au (II) Complex & Eo (V vs SHEa) & Stability Constants $ß 2$ or $\$ 4$ & pH Range \\
\hline $\mathrm{CN}^{-}$ & $\mathrm{Au}(\mathrm{CN})^{2-}$ & -0.57 & 38.3 & $>9$ \\
\hline $\mathrm{S}_{2} \mathrm{O}_{3}{ }^{2-}$ & $\mathrm{Au}\left(\mathrm{S}_{2} \mathrm{O}_{3}\right)_{2}{ }^{3-}$ & 0.17 & 28.7 & 8 to 10 \\
\hline $\mathrm{CS}\left(\mathrm{NH}_{2}\right)_{2}$ & $\mathrm{Au}\left(\mathrm{NH}_{2} \mathrm{CSNH}_{2}\right)_{2}^{+}$ & 0.38 & 23.3 & $<3$ \\
\hline $\mathrm{Cl}^{-}$ & $\mathrm{AuCl}_{2}^{-}, \mathrm{AuCl}_{4}^{-}$ & $1.11,1$ & $9.1,25.3$ & $<3$ \\
\hline $\mathrm{Br}^{-}$ & $\mathrm{AuBr}_{2}^{-}, \mathrm{AuBr}_{4}^{-}$ & $0.98,0.97$ & $12,32.8$ & 5 to 8 \\
\hline $\mathrm{I}^{-}$ & $\mathrm{AuI}_{2}^{-}, \mathrm{AuI}_{4}^{-}$ & $0.58,0.69$ & $18.6,47.7$ & 5 to 9 \\
\hline $\mathrm{HS}^{-}$ & $\mathrm{Au}(\mathrm{HS})_{2}^{-}$ & -0.25 & 29.9 & $<9$ \\
\hline $\mathrm{NH}_{3}$ & $\mathrm{Au}\left(\mathrm{NH}_{3}\right)_{2}{ }^{+}$ & 0.57 & 26.5 & $>9$ \\
\hline Glycinate & $\mathrm{Au}\left(\mathrm{NH}_{2} \mathrm{CH}_{2} \mathrm{COO}\right)_{2}^{-}$ & 0.632 & 18 & 9 \\
\hline $\mathrm{SCN}^{-}$ & $\left.\mathrm{Au}(\mathrm{SCN})_{2}^{-}, \mathrm{Au} \mathrm{SCN}\right)_{4}^{-}$ & $0.66,0.66$ & $17.1,43.9$ & $<3$ \\
\hline $\mathrm{SO}_{3}{ }^{2-}$ & $\mathrm{Au}\left(\mathrm{SO}_{3}\right)_{2}{ }^{3-}$ & 0.77 & 15.4 & $>4$ \\
\hline
\end{tabular}

The wide range of values of the stability constants for the gold complexes indicates that the standard reduction for the different gold ligand species varies by almost $2 \mathrm{~V}$. Most reagents have a small operating window for effectively dissolving cyanide compared with cyanide, as shown in Figure 5. The high oxidizing potentials involved with some lixiviants lead to high reagent consumptions due to reaction with sulfide minerals contained in the ore and the oxidation of the reagent itself. A point to consider is that the adsorption of reagents and/or precipitation of gold onto some gangue minerals that can affect the overall gold recovery. 


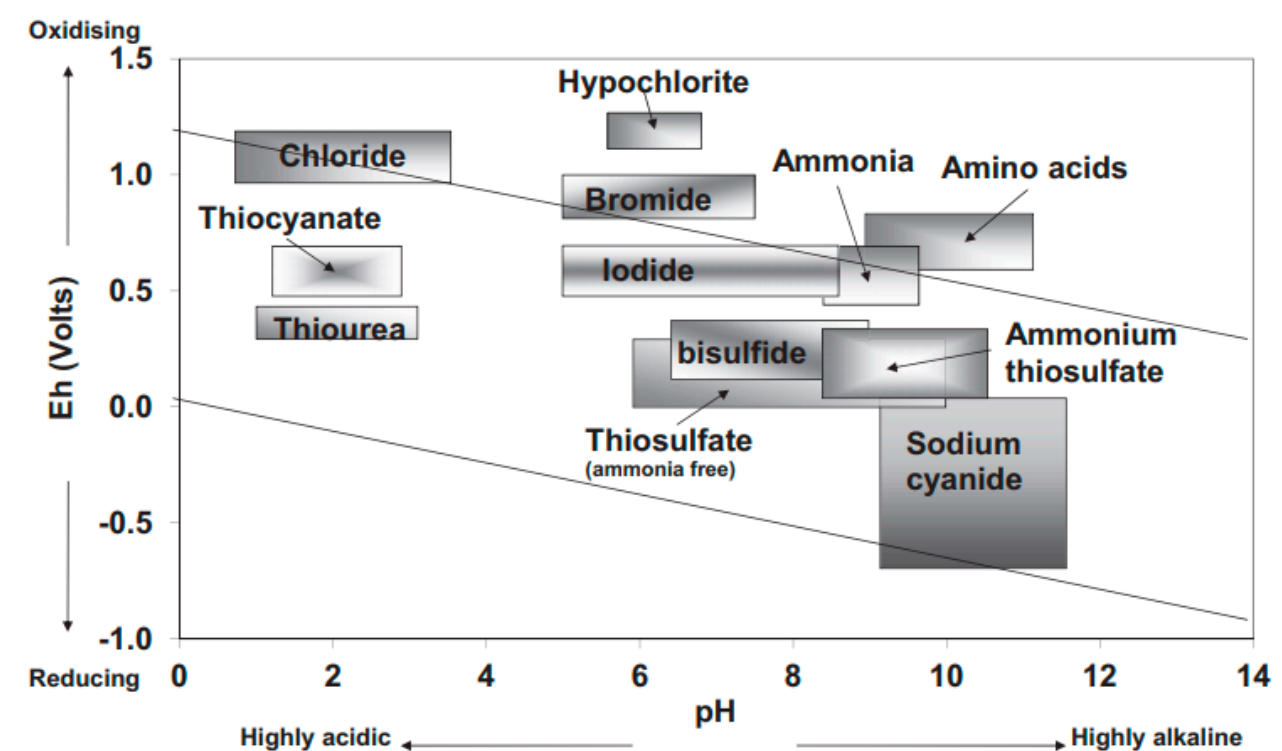

Figure 5. Diagram showing the typical range of operation of lixiviants. Reproduced and adapted from [22], with the permission from Elsevier B.V., 2016.

\section{Carbon Adsorption}

The formation of copper and silver cyanide complexes also affects the adsorption of gold during the CIP stage during the leaching. The metal-cyanide species adsorption occurs in a selective form, depending on the ionic diameters of the metal-cyanide complexes. The adsorption of metal-cyanides on activated carbon is selective, and the most potent adsorbed complex is $\mathrm{Au}(\mathrm{CN})^{2-}$. On the other hand, silver-cyanide complex $\mathrm{Ag}(\mathrm{CN})^{2-}$ adsorbs strongly but not as strongly as the gold-cyanide complex [23].

The copper-cyanide complexes $\mathrm{Cu}(\mathrm{CN})^{2-}$ and $\mathrm{Cu}(\mathrm{CN})_{3}{ }^{2-}$ show different adsorption features, with the $\mathrm{Cu}(\mathrm{CN})^{2-}$ complex adsorbing more strongly than the $\mathrm{Cu}(\mathrm{CN})_{3}{ }^{2-}$ complex [24]. The hydration is an essential aspect of carbon adsorption because it causes metal-cyanide complexes to increase their molecule diameter due to the fact that the metal ion is likely to have had a predetermined hydration that can affect the metal-cyanide carbon adsorption. The classification of those that are most strongly adsorbed to those that are the least absorbed is: $\mathrm{Au}>\mathrm{Ag}>\mathrm{Cu}$, where the $\mathrm{Ag}$ and $\mathrm{Cu}$ have an effect on the gold recovery during the leaching process [23].

Maintaining a high free-cyanide concentration reduces the concentration of more adsorbed copper complexes. The increase of copper cyanide adsorption at low cyanide concentrations results in problems for gold adsorption, as previously mentioned [25].

\section{Processing Options}

Different options have been developed for the treatment of copper-gold ores. Approximately $20 \%$ of all gold deposits have significant copper mineralization associated with chalcopyrite, tetrahedrite, tennantite, bornite, and chalcocite. Most of the copper minerals, including copper oxides, carbonates, sulfides (with the exception of chalcopyrite), and native copper are highly soluble in cyanide solutions. As mentioned previously, the minerals that contain copper are problematic because during the gold cyanidation process, the copper also forms cyanide complexes, thereby consuming the cyanide $[6,25]$.

The presence of copper-cyanide complexes creates competition with the gold during the activated adsorption; it also affects the electrowinning efficiency. Research has been undertaken relating to the treatment of copper-gold ores, as well as to the lowering of the effects of copper-cyanide complexes. Some of the processing options include $[25,26]$ :

(1) Ore Segregation Technologies 
Separating high-copper-containing ores selectively prior to the leaching process is an option in order to reduce the impact of the copper content. For example, the Red Dome Mine in Australia selectively mines and leaches ores containing less than $0.5 \%$ copper [25].

\section{(2) Selective Leaching Technologies}

Another processing option is to selectively leach the copper contained in the ores containing gold prior to the gold leaching. These processes are often associated to high reagent consumption and also to recovery issues of the leached copper. Studies have been undertaken on the application of copper/ammonia/cyanide processes for the treatment of copper-containing ores. These studies have shown that the addition of ammonia to the cyanide solution results in a lower cyanide consumption and a higher selectivity of gold leaching over copper. However, the rate of gold leaching is slower in this system when ammonia is used; in addition, it also represents an occupational health and environmental concern [24].

\section{(3) Copper-Cyanide Destruction Technologies}

This type of process uses $\mathrm{SO}_{2}$ combined with air to produce cyanide oxidation to cyanite, whereby the copper is precipitated at the end of the reaction as copper hydroxide [27]. There are alternative processes for cyanide destruction such as alkaline chlorination, the use of hydrogen peroxide (Degussa process), the use of Caro's acid, electrochemical oxidation, biodegradation, the use of ultrasonic technology, or photolysis [5].

\section{Sulfidization, Acidification, Recycling and Thickening (SART) Technology}

Recently, new processes have been developed to treat the main issues previously mentioned about processing complex copper ores for gold recovery. One of these processes is the SART process. SGS Lakefield Group and Teck Corporation developed the SART process in the 1990s [26]. The benefit of having a SART process in the cyanidation process is that it breaks the base metal cyanide complexes, precipitates the metals as high-grade sulfide concentrates, and frees the cyanide for recirculation to the leaching process [28]. The SART process is described by the following sequence of unit operations:

Sulfidization and Acidification: During this stage, the cyanide solution is mixed with sodium hydrosulfide $\mathrm{NaSH}$ and $\mathrm{H}_{2} \mathrm{SO}_{4}$ to decrease the $\mathrm{pH}$ between $4-5$ to form $\mathrm{Cu}_{2} \mathrm{~S}$, using a precipitator reactor and thickener to form a $\mathrm{Cu}_{2} \mathrm{~S}$ precipitate as a co-product. Equations (4) and (5) show the reactions during this process [29]:

$$
\begin{gathered}
2 \mathrm{NaCN}+\mathrm{H}_{2} \mathrm{SO}_{4} \rightarrow 2 \mathrm{HCN}(\mathrm{aq})+\mathrm{Na}_{2} \mathrm{SO}_{4} \\
4 \mathrm{Na}_{2} \mathrm{Cu}(\mathrm{CN})_{3}+2 \mathrm{NaSH}+5 \mathrm{H}_{2} \mathrm{SO}_{4} \rightarrow 2 \mathrm{Cu}_{2} \mathrm{~S}(\mathrm{~s})+12 \mathrm{HCN}(\mathrm{aq})+5 \mathrm{Na}_{2} \mathrm{SO}_{4}
\end{gathered}
$$

Equation (4) shows the solution acidification, which promotes the dissociation of weak metal-cyanide complexes (WAD complexes), such as $\mathrm{Cu}$ and $\mathrm{Ag}$ metals. Equation (5) involves the precipitation of soluble metal ions formatting metallic sulfides such as $\mathrm{Cu}_{2} \mathrm{~S}$. The $\mathrm{Cu}$ precipitation efficiency under standard process conditions is between $80 \%$ and $90 \%$. [29].

Recycling: The remaining solution containing $\mathrm{HCN}$ is neutralized using $\mathrm{CaO}$ to reach a $\mathrm{pH}$ between 10 and 11 to form $\mathrm{CaSO}_{4}$ (Gypsum) and to recycle the cyanide, respectively. The formed solid gypsum is then removed from the process by thickening and filtration, as shown on in Equations (6) and (7) [29]:

$$
\begin{gathered}
2 \mathrm{HCN}(\mathrm{aq})+\mathrm{Ca}(\mathrm{OH})_{2} \rightarrow \mathrm{Ca}(\mathrm{CN})_{2}+2 \mathrm{H}_{2} \mathrm{O} \\
\mathrm{H}_{2} \mathrm{SO}_{4}+\mathrm{Ca}(\mathrm{OH})_{2} \rightarrow \mathrm{CaSO}_{4} \cdot 2 \mathrm{H}_{2} \mathrm{O}(\mathrm{s})
\end{gathered}
$$

Thickening: The gypsum is precipitated using a settler and a flocculent to separate the solution $\mathrm{Ca}(\mathrm{CN})_{2}$ and the gypsum. The cyanide is recycled in the process, and the gypsum is precipitated for 
disposal. The overflow solution from the gypsum thickener is filtered and represents the final solution. This solution has a cyanide content, represented as $\mathrm{Ca}(\mathrm{CN})_{2}$, that is equivalent to the free cyanide that is recycled in the cyanidation process [29].

These unit operations of the SART process describe the treatment of the cyanide solution after the stripping of the activated carbon. Figure 6 shows the general flowsheet of the SART process:

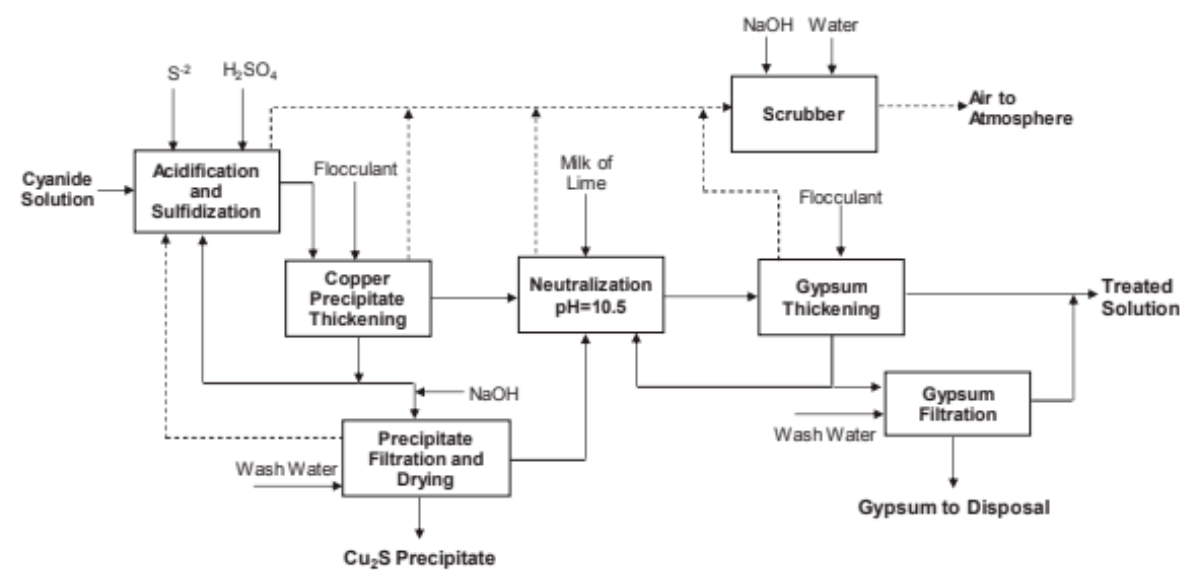

Figure 6. SART process flowsheet. Reproduced and adapted from [16], with permission from PERGAMON, 2020.

The SART process reduces the issues caused by the copper-cyanide complexes during the cyanide leaching process. It recycles the cyanide to diminish the cyanide consumption and provides operational cost savings. It avoids having free cyanide disposal, which can be a hazard for the environment [30]. Additionally, the formation of $\mathrm{Cu}_{2} \mathrm{~S}$ as a saleable product is one of the essential advantages of the SART process within cyanide leaching, because of the way it economically takes advantage of the copper content. The ideal performance of the SART process and thickening operation would be to produce a clean solution and to separate the solids from the treated solution in the thickener [31].

\section{Conclusions}

The challenges of treating ores and concentrates with copper, silver, and gold have increased significantly as mineralogies have become more complex. Hence, the technology for such treatment has been forced to become more efficient and innovative in order to face these current challenges. The application of the cyanidation process in conjunction with the SART process represents an innovative way to diminish the problems of having deleterious cyanide complexes involved in the process, by recovering marketable copper and silver sulfides. As a result, the carbon circuit can be made smaller and designed primarily for gold recovery. There are also environmental advantages in the application of these processes, including the reduction of dangerous chemical exposure to the environment.

Author Contributions: Conceptualization, D.M. and C.G.A.; methodology, D.M. and C.G.A.; D.M. and C.G.A.; validation, D.M. and C.G.A.; formal analysis, D.M. and C.G.A.; investigation, D.M. and C.G.A.; resources, D.M. and C.G.A.; data curation, D.M. and C.G.A.; writing-original draft preparation, D.M.; writing-review and editing, D.M.; visualization, D.M.; supervision, C.G.A.; project administration, C.G.A.; funding acquisition, C.G.A. All authors have read and agreed to the published version of the manuscript.

Funding: Research was funded by NEMISA, 470120.

Conflicts of Interest: The authors declare no conflict of interest.

\section{References}

1. Adams, M.D. Advantages in Gold Ore Processing, 1st ed.; Elsevier B.V.: Perth, Australia, 2005. 
2. Twidwell, L.G. Montana College of Mineral Science and Technology Unit Processes in Extractive Metallurgy: Hydrometallurgy. 1970; p. 16. Available online: https:/files.eric.ed.gov/fulltext/ED218136.pdf (accessed on 6 January 2020).

3. Lee, K.; Archibald, D.; McLean, J.; Reuter, M.A. Flotation of mixed copper oxide and sulphide minerals with xanthate and hydroxamate collectors. Miner. Eng. 2008, 22, 1-7. [CrossRef]

4. Sokic, M.D.; Milosevic, V.D.; Stankovic, V.D.; Matkovic, L.V.; Markovic, B.R. Acid leaching of oxide-sulfide copper ore prior the flotation-A way for an increased metal recovery. Hemijska Industrija 2015, 69, 454-458. [CrossRef]

5. McClelland, G.E.; McPartland, J.S. Metallurgical Comparisons from Testing to Production. Adv. Gold Silver Process. 1990, 1, 49-57.

6. Deschenes, G. Advances in the cyanidation of gold. Dev. Miner. Process. 2005, 15, 479-500.

7. Brittan, M.; Plenge, G. Estimating Process Design Gold Extraction, Leach Residence Time and Cyanide Consumption for High Cyanide-Consuming Gold Ore. Miner. Metall. Process 2015, 32, 111-120. [CrossRef]

8. Sceresini, B. Gold-copper ores. In Advantages in Gold Ore Processing, 1st ed.; Adams, M.D., Ed.; Elsevier B.V: Perth, Australia, 2005; pp. 789-821.

9. Hill Stephen, D. The carbon-in-pulp process. In Precious Metals Recovery from Low-Grade Resources; Bureau of Mines: Washington, DC, USA, 1986; pp. 40-43.

10. Breuer, P.L.; Rumball, J.A. Cyanide Measurement and Control for Complex Ores and Concentrates. In Proceedings of the Ninth Mill Operators Conference, Fremantle, WA, Australia, 19-21 March 2007; AusIMM: Victoria, Australia, 2007; pp. 249-253.

11. Estay, H. Designing the SART process-A review. Hydrometallurgy 2018, 176, 147-165. [CrossRef]

12. Thompson, P.; Runge, K.; Dunne, R. Sulfide Flotation testing. In Mineral Processing and Extractive Metallurgy Handbook, 1st ed.; Society for Mining, SME: Englewood, CO, USA, 2019; pp. 1029-1031.

13. Medina, D.; Anderson, C. Tailings Gold Recovery by Cyanide Leaching from Future Ores. Master' Thesis, Colorado School of Mines, Golden, CO, USA, 2020, (unpublished).

14. Xie, F.; Dreisinger, D.; Doyle, F. A review on recovery of copper and cyanide from waste cyanide solutions. Miner. Process. Extr. Metall. Rev. 2013, 34, 387-411. [CrossRef]

15. Markovic, Z.; Vusovic, N.; Milanovic, D. Old Copper Flotation Tailings Water Reprocessing. In Proceedings of the XXV International Mineral Processing Congress (IMPC) Proceedings, Brisbane, QLD, Australia, 6-10 September 2010; Australian Institute of Mining and Metallurgy: Brisbane, Australia, 2010; pp. 3825-3829.

16. Haque, K.E. The Role of Oxygen in Cyanide Leaching of Gold Ore. CIM Bull. 1992, 85, 31-38.

17. Anderson, C.G. Alkaline Sulfide Gold Leaching Kinetics. Miner. Eng. 2016, 92, 248-256. [CrossRef]

18. Barsky, G.; Swainson, S.J. Dissolution of Gold and Silver in Cyanide Solutions. Trans. AIME 1943, 112, 660-667.

19. Estay, H.; Minghai, G.K.; Gabriel, S.; Quilaqueo, M.; Barros, L.; Figueroa, R.; Troncoso, E. Optimizing the SART process: A critical assessment of its design criteria. Miner. Process. 2020, 146, 1-11. [CrossRef]

20. Zarate, G.E. Gold Tailings Processing by Heap Leaching. In Small Mines Development in Precious Metals; Society of Mining Engineers: Santiago, Chile, 1987; pp. 152-155.

21. Prasad, M.S.; Mensah, B.R.; Pizarro, R.S. Modern Trends in Gold Processing-Overview. Miner. Eng. 1991, 4, 1257-1277. [CrossRef]

22. Aylmore, M.G. Alternative Lixiviant to Cyanide for Leaching Gold Ores. In Gold Ore Processing: Project Development and Operations, 2nd ed.; Adams, M.D., Ed.; Elsevier B.V.: Amsterdam, The Netherlands, 2016; pp. 447-460.

23. Sayiner, B.; Acarkan, N. Effect of Silver, Nickel and Copper Cyanides on Gold Adsorption on Activated Carbon. Physicochemical Prob. Miner. Process. 2013, 50, 277-287.

24. Muir, D.M.; La Brooy, S.R.; Fenton, K. Processing copper-gold ores with ammonia or ammonia cyanide solutions. World Gold 1991, 91, 145-150.

25. Dai, X.; Simons, A.; Breuer, P. A review of copper cyanide recovery technologies for the cyanidation of copper containing gold ores. Miner. Eng. 2012, 25, 1-13. [CrossRef]

26. Littlejohn, P.; Kratochvil, D.; Hall, A. Sulfidisation-Acidification-Recycling-thickening for Complex Ores. In Proceedings of the World Gold, Brisbane, Australia, 26-29 September 2013; pp. 149-155. 
27. Nicol, M.J.; Fleming, C.A.; Paul, R.L. The Chemistry of the Extraction of Gold. In The Chemistry of Gold Extraction; Marsden, J., House, I., Eds.; SME: Littleton, CO, USA, 2006; pp. 831-905.

28. Kratochvil, D.; Salari, D.; Avilez, T. SART Implementation at Heap Leach Operations in Mexico. In Proceedings of the 50th Annual Canadian Mineral Processors Operators Conference, Ottawa, ON, Canada, 24 January 2018; CIM: Ottawa, ON, Canada; pp. 1-13.

29. Estay, H.; Carvajal, P.; Hedjazi, F.; Zeller, T.V. The SART process experience in the Gedabel plant. In Proceedings of the 4th International Workshop on Process Hydrometallurgy, Santiago, Chile, 12-13 July 2012; Gecamin: Santiago, Chile; pp. 1-10.

30. Kevan, J.R.F.; Robert, D.H. Application of the SART Process to Heap Leaching. SGS Miner. Serv. Tech. Bull. 2008, 51, 1-12.

31. Estay, H.; Becker, J.; Carvajal, P.; Arriagada, F. Predicting HCN gas genertion in the SART process. Hydrometallurgy 2012, 113, 131-142. [CrossRef]

(C) 2020 by the authors. Licensee MDPI, Basel, Switzerland. This article is an open access article distributed under the terms and conditions of the Creative Commons Attribution (CC BY) license (http://creativecommons.org/licenses/by/4.0/). 